\title{
KANDUNGAN BAHAN ORGANIK FOSFOR (P) PADA SEDIMEN BERDASARKAN KEDALAMAN DI HUTAN MANGROVE MAMBURUNGAN KOTA TARAKAN
}

\section{ORGANIC MATERIAL CONTENT OF PHOSPHORUS (P) IN SEDIMENTS BASED ON THE DEPTH OF THE MANGROVE FOREST IN MAMBURUNGAN THE TOWN OF TARAKAN}

\author{
Yulma ${ }^{1)}$, Encik Weliyadi ${ }^{2)}$, Resta Yulinar ${ }^{3)}$ \\ $1,2,3)$ Jurusan Manajemen Sumberdaya Perairan \\ Fakultas Perikanan dan Ilmu Kelautan \\ Universitas Borneo Tarakan \\ Jalan Amal Lama Nomor 1, Tarakan \\ Email: ${ }^{1}$ yulma.yuki@gmail.com
}

\begin{abstract}
ABSTRAK
Bahan organik fosfor $(P)$ dalam sedimen memainkan peranan dalam fotosintesis, penggunaan gula dan Pati, dan pengalihan energi yang dibutuhkan oleh tanaman dan organisme dalam sedimen. Kajian ini bertujuan untuk menentukan kandungan fosfor $(P)$ dalam sedimen berdasarkan kedalaman $10 \mathrm{~cm}, 20$ $\mathrm{cm}$ dan $30 \mathrm{~cm}$ di kawasan hutan bakau Mamburungan Tarakan. Studi ini dimulai pada bulan Februari sampai dengan Juli 2018 metode yang digunakan dalam studi ini adalah kuantitatif deskriptif dengan menjelaskan isi dari fosfor berdasarkan kedalaman pada setiap stasiun penelitian. Pengambilan sampel sedimen dilakukan di 3 titik Stasiun, yaitu daerah akuakultur, pemukiman dan mulut Sungai dengan 3 pengulangan. Dari hasil kajian yang diperoleh nilai bahan organik fosfor dalam sedimen daerah hutan mangrove Mamburungan berdasarkan kedalaman $10 \mathrm{~cm}$ berkisar dari 10,11-101,15 mg/L, $20 \mathrm{~cm}$ berkisar dari 7,04-141,98 mg/L dan $30 \mathrm{~cm}$ berkisar dari 29. 41-66,88 mg/L.
\end{abstract}

\section{Kata Kunci : Bahan Organik, Fosfor, Mamburungan, Mangrove, Sedimen}

\begin{abstract}
Organic substances Phosphorus $(P)$ in sediment plays a role in photosynthesis, the use of sugar and starch, and the transfer of energy needed by plants and organisms in the sediment. This study aims to determine the phosphorus content $(P)$ in sediments based on a depth of $10 \mathrm{~cm}, 20 \mathrm{~cm}$ and $30 \mathrm{~cm}$ in the Mangrove Forest Area of Mamburungan Tarakan. This study started from February to July 2018 the method used in this study is quantitative descriptive by describing the content of Phosphorus based on depth at each research station. Sediment sampling was carried out in 3 station points, namely the aquaculture area, settlement and river mouth with 3 repetitions. From the results of the study obtained the value of the organic material Phosphorus in the sediments of Mangrove Forest Area Mamburungan based on $10 \mathrm{~cm}$ depth ranged from $10.11-101.15 \mathrm{mg} / \mathrm{L}, 20 \mathrm{~cm}$ ranged from $7.04-141.98 \mathrm{mg} / \mathrm{L}$ and $30 \mathrm{~cm}$ ranged from 29. $41-66.88 \mathrm{mg} / \mathrm{L}$.
\end{abstract}

Keywords: Organic Material, Phosphorus, Mamburungan, Mangrove, Sediment

\section{PENDAHULUAN}

Hutan mangrove adalah komunitas vegetasi pantai tropis dan merupakan komunitas yang hidup di dalam kawasan yang lembab dan berlumpur serta dipengaruhi oleh pasang surut air laut (Feller et. al., 2010; Mahasani et al.,
2015). Didalam ekosistem mangrove terjadi proses rantai makanan yang berasal dari serasah mangrove yang terurai menjadi bahan organik, baik bahan organik di perairan maupun yang mengendap di sedimen. Tarakan memiliki 
daerah hutan mangrove, salah satunya di bagian Tarakan Timur yaitu Kelurahan Mamburungan. Ekosistem mangrove di Kelurahan Mamburungan merupakan salah satu hutan konservasi yang telah ditetapkan oleh pemerintah Kota Tarakan sejak tahun 2006. Sesuai dengan BPS Tarakan dalam angka (2015) diketahui bahwa hutan mangrove Mamburungan memiliki luas 203,00 Ha terdiri dari beberapa vegetasi mangrove seperti Rhizopora $s p$, Sonneratia $s p$ dan Avicennia $s p$ dengan substrat yang berlumpur dan berpasir.

Hutan mangrove memiliki fungsi fisik seperti untuk menjaga garis pantai agar tetap stabil, mangrove juga berfungsi sebagai penangkap sedimen beserta dengan unsur-unsur organik yang terdapat di perairan. Mardi (2014) menyatakan bahwa sumber sedimen di kawasan mangrove berasal dari daratan maupun lautan (allocthonous) dan dari kawasan mangrove itu sendiri (autochtonous) yang berupa timbunan guguran daun, ranting, dan organisme mati yang terdeposisi di daerah mangrove dan mengandung banyak bahan organik seperti Mineral, Kalium, Besi, Magnesium, Nitrogen, Fosfor ( $\mathrm{K}, \mathrm{Fe}, \mathrm{Mg}, \mathrm{N}$ dan P) dan Fosfor merupakan salah satu bahan organik yang diperlukan dalam jumlah besar (organik makro).

Fosfor dianggap sebagai kunci kehidupan (key of life) (Rosmarkam, 2002). Ketersediaan Fosfor di tanah sekitar 0,01 - 0,1 \% dari keseluruhan senyawa di tanah, jumlah Fosfor dalam tanaman lebih kecil dibandingkan dengan Kalium dan Nitrogen. Unsur Fosfor berperan dalam proses fotosintesis, penggunaan gula dan pati, serta transfer energi. Defesiensi fosfor mengakibatkan pertumbuhan tanaman lambat, lemah, dan kerdil (Sutanto, 2005).

Keberadaan bahan organik dalam sedimen berbeda-beda, kandungan bahan organik di dasar perairan mempunyai nilai yang lebih tinggi dibandingkan di permukaan (Muchtar, 2012). Nugroho et. al., (2013) dalam penelitiannya memperoleh bahwa kandungan bahan organik pada kedalaman $20 \mathrm{~cm}$ sedikit lebih tinggi mengandung bahan organik Fosfor dibandingkan kedalaman $10 \mathrm{~cm}$ dan $30 \mathrm{~cm}$. Berdasarkan referensi tersebut, sehingga perlu dilakukan penelitian tentang kandungan bahan organik Fosfor ( $P$ ) pada sedimen berdasarkan kedalaman di Hutan Mangrove Mamburungan Kota Tarakan.

Tujuan dari penelitian ini adalah untuk mengetahui kandungan fosfor $(P)$ pada sedimen berdasarkan kedalaman di kawasan hutan mangrove Kelurahan Mamburungan Kota Tarakan.

\section{METODE PENELITIAN}

\section{Tempat dan Waktu}

Penelitian ini dilaksanakan pada bulan Februari sampai dengan bulan Juli 2018. Lokasi penelitian dilakukan di Hutan Mangrove Mamburungan Kota Tarakan. Analisis fraksi tanah dilakukan dan analisis kandungan fosfor (P) di Labolatorium Tanah Fakultas Pertanian Universitas Borneo Tarakan. Peta lokasi penelitian disajikan pada Gambar 1.

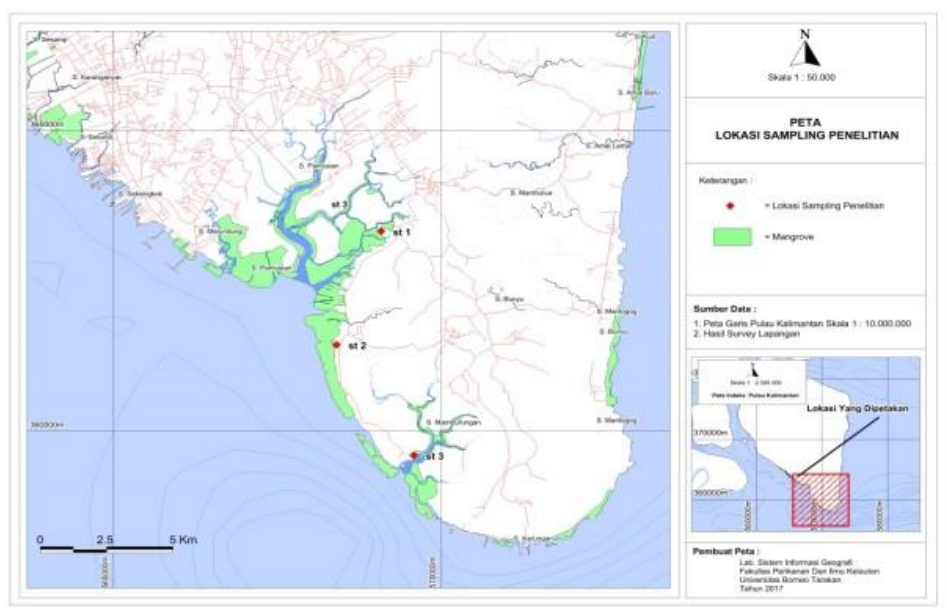

Gambar 1. Peta Lokasi Sampling Penelitian 
Metode yang digunakan dalam penelitian adalah metode deskriptif kuantitatif. Sugiyono (2016) menyatakan bahwa penelitian diskriptif adalah penelitian yang dilakukan untuk mengetahui nilai variabel mandiri, baik satu variabel atau lebih (independen). Sedangkan kuantitatif merupakan penelitian dengan memperoleh data yang berbentuk angka.

\section{Alat dan Bahan}

Alat yang digunakan dalam penelitian ini sebagai berikut adalah: GPS,

cawan petri, timbangan analitik, skop kecil, oven, cool box, penggerus, biopori, pH meter, DO meter, refraktometer.

Bahan yang digunakan dalam penelitian ini sebagai berikut adalah: sedimen, kantong plastik, aquades, $\mathrm{NaOH}$, larutan asam borat, tablet kjeldhal, extraction $\mathrm{p}$, tablet regent $\mathrm{p}$.

\section{Prosedur Kerja}

Penelitian ini dilakukan dengan menentukan stasiun sampling. Stasiun pengamatan terdiri dari 3 stasiun berdasarkan karakteristik hutan mangrove di kelurahan Mamburungan. Stasiun I terletak di daerah pertambakan, stasiun II terletak daerah pemukiman dan stasiun III terletak daerah aliran sungai. Selanjutnya pengambilan sampel dilakukan pada kedalaman sedimen yang berbeda yaitu: $10 \mathrm{~cm}, 20 \mathrm{~cm}$ dan $30 \mathrm{~cm}$. Pengambilan sampel menggunakan alat bio pori dan pengulangan pengambilan sampel dilakukan sebanyak tiga kali di setiap sub stasiun tersebut kemudian dibungkus kertas alumunium setelahnya dimasukkan ke dalam coolbox lalu dibawa ke laboratorium. Setelah pengambilan sampel dilakukan analisis kandungan fosfor dengan metode Bray I. Adapun cara kerja dalam melakukan analisis bahan organik Fosfor yaitu, timbang 2,5 gram contoh tanah $<2 \mathrm{~mm}$, tambah pengekstrak bray dan kurt 1 sebanyak 2,5 mL, kemudian kocok selama 5 menit, saring dan bila larutan keruh kembalikan ke atas saringan semula (proses penyaringan maksimum 5 menit). Lalu pipet $2 \mathrm{~mL}$ ekstrak jernih kedalam ke tabung reaksi. Sebanyak 10 ml, dikocok dan dibiarkan 30 menit. Diukur absorbansinya dengan spektrofotometer pada panjang gelombang $889 \mathrm{~nm}$.

Pengukuran kualitas air dilakukan untuk mengetahui kondisi lingkungan dan pengaruh terhadap kandungan fosfor pada sedimen di hutan mangrove Mamburungan diantaranya adalah suhu, salinitas, DO dan $\mathrm{pH}$.

Bahan Organik dioksidasi dengan $\mathrm{H}_{2} \mathrm{O}_{2}$ dan garam yang mudah larut dihilangkan dari tanah dengan $\mathrm{HCl}$ sambil dipanaskan. Bahan yang tersisa adalah mineral yang terdiri atas pasir, debu, dan liat. Pasir dapat dipisahkan dengan cara pengayakan basah, sedangkan debu dan liat dipisahkan dengan cara pengendapan yang didasarkan pada hukum Stoke dan menggunakan segitiga tekstur tanah dalam menentukan jenis tanah yang disajikan pada Gambar 2.

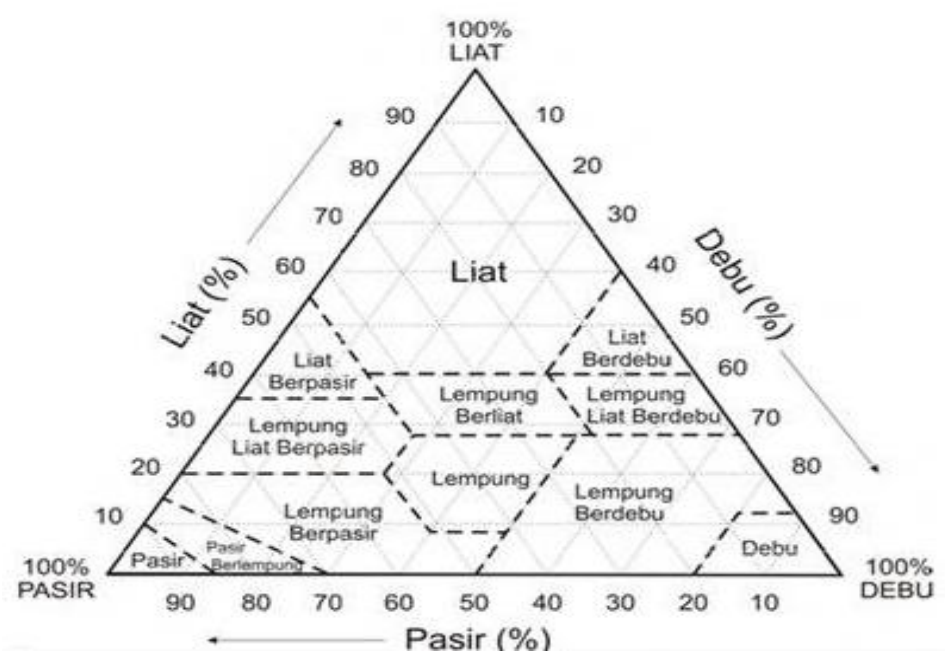

Gambar 2. Segitiga Tekstur Tanah 


\section{Analisis Data}

Untuk mengetahui hasil dari bahan organik fosfor dapat dilakukan dengan metode Metode Bray I (1945). Perhitungan :

\section{Kadar $\mathbf{P}_{\mathbf{2}} \mathrm{O}_{\mathbf{5}}$ tersedia (ppm) : \\ $=\mathrm{ppm}$ kurva $\times \mathrm{ml}$ ekstrak $/ 1000 \mathrm{ml} \times 100 \mathrm{gr}(\mathrm{g}$ contoh $)^{-1} \times \mathrm{fp} \times 142 / 190 \times \mathrm{fk}$ \\ $=$ ppm kurva $\times 25 / 1000 \times 1000 / 2,5 \times \mathrm{fp} \times$ $142 / 190 \times \mathrm{fk}$ \\ $=p p m$ kurva $\times 10 \times \mathrm{fp} \times 142 / 190 \times \mathrm{fk}$}

\section{Keterangan :}

Ppm kurva

: Kadar contoh yang didapat dari kurva hubungan antara kadar deret standar dengan pembacanya setelah dikoreksi blangko.

$\mathrm{Fp}$

$142 / 190$

FK
: Faktor Pengenceran (bila ada)

: Faktor konversi bentuk $\mathrm{PO}_{4}$ menjadi $\mathrm{P}_{2} \mathrm{O}_{5}$

: Faktor koreksi kadar air $=100 /(100-\%$ kadar air $)$
Data analisis penelitian fosfor disajikan dalam bentuk grafik dan tabel. Selanjutnya, dilakukan analisis menggunakan Microsoft excel untuk mengetahui adanya perbedaan kandungan nitrogen antar kedalaman sedimen.

\section{HASIL DAN PEMBAHASAN}

Secara geografis, lokasi penelitian berada di bagian pesisir kecamatan Tarakan Timur yang berada di antara sungai Pamusian dan sungai Mamburungan, yang masuk ke dalam wilayah kelurahan Mamburungan. Menurut Wiharyanto et. al., (2010) bahwa Hutan Mangrove di kawasan konservasi desa Mamburungan, diketahui terdapat tiga jenis vegetasi mangrove primer. Mangrove tersebut terdiri dari beberapa jenis yaitu Rhizopora $s p$, Sonneratia $s p$, dan Avicennia sp. Selain itu terdapat Jenis biota lain yang menempati substrat lumpur liat berdebu adalah beberapa jenis crutacea, gastropoda, serta berbagai jenis biota lainnya.

Adapun titik koordinat lokasi penelitian yang didapatkan melalui Geograpical Position System (GPS) yang disajikan pada Tabel 1.

Tabel 1. Titik Koordinat Lokasi Penelitian

\begin{tabular}{llll}
\multirow{2}{*}{ Stasiun } & \multicolumn{2}{c}{ Titik Koordinat } & \multirow{2}{*}{ Keterangan } \\
\cline { 2 - 3 } & \multicolumn{2}{c}{ Bujur } & \multicolumn{1}{c}{ Lintang } \\
\hline 1 & $117^{\circ} 43^{\prime} 59,88^{\prime \prime} \mathrm{W}$ & $3^{\circ} 20^{\prime} 13,20^{\prime \prime} \mathrm{S}$ & Pertambakan \\
2 & $117^{\circ} 49^{\prime} 9,84^{\prime \prime} \mathrm{W}$ & $3^{\circ} 10^{\prime} 40,08^{\prime \prime} \mathrm{S}$ & Pemukiman \\
3 & $117^{\circ} 46^{\prime} 34,00^{\prime \prime} \mathrm{W}$ & $3^{\circ} 18^{\prime} 15,01^{\prime \prime} \mathrm{S}$ & Muara Sungai \\
\hline
\end{tabular}

Stasiun 1 terletak di kawasan pertambakan yang berada dekat aliran sungai Pamusian. Pada lokasi ini terdapat beberapa jenis mangrove yang lebih dominan antara lain Rhizopora s dan Avicennia sp, sebagian besar wilayah ini sudah mengalami degradasi, karna telah beralih fungsi menjadi lahan pertambakan. Selain itu, terdapat biota seperti ikan tempakul dan beberapa jenis gastropoda lainnya yang menempel di badan pohon mangrove maupun di sedimen.

Stasiun 2 terletak di kawasan pemukiman penduduk dan terdapat jenis mangrove yang didominasi oleh Rhizopora $s p$ dan Avicennia $s p$. Selain itu, terdapat biota seperti ikan tempakul dan beberapa jenis gastropoda lainnya yang menempel di badan pohon mangrove maupun di sedimen. Pada stasiun ini juga terdapat buangan limbah plastik yang berasal dari aktfitas masyarakat sekitar. ng langsung terkena arus pasang surut.

Stasiun 3 terletak di kawasan sungai mamburungan dekat dengan muara yang didominasi oleh jenis mangrove Rhizopora $s p$, Sonneratia sp, Avicennia sp dan Nipah. Selain itu, terdapat biota seperti ikan tempakul, beberapa jenis crustacea dan beberapa jenis gastropoda lainnya yang menempel di badan pohon mangrove maupun di sedimen. Pada stasiun ini memiliki jumlah tumbuhan mangrove 
yang lebih banyakn karna letaknya yang dialiri air sungai membuat tumbuhan mangrove mendapatkan nutrisi dengan baik dan terdapat jenis organisme yang melimpah.

\section{Analisis Substrat}

Tekstur dari sedimen dapat mempengaruhi jumlah kandungan organik yang mengendap. Semakin halus tekstur dari sedimen perairan semakin banyak pengendapan bahan organik. Sanusi dan Putranto (2009) menyatakan bahwa sedimen yang memiliki tekstur halus biasanya berada pada hilir dan estuari, sedangkan untuk tekstur sedimen kasar biasanya berada pada daerah yang memiliki kondisi arus dinamis seperti daerah yang mengarah ke laut lepas. Analisis substrat dapat dilihat pada Tabel 2.

Tabel 2. Analisis Tekstur Substrat

\begin{tabular}{cccccc}
\hline \multirow{2}{*}{ Stasiun } & $\begin{array}{c}\text { Kedalaman } \\
(\mathbf{c m})\end{array}$ & \multicolumn{3}{c}{ Persentase (\%) } & \multirow{2}{*}{ Jenis Tekstur } \\
\cline { 3 - 5 } & 10 & Pasir & Debu & Liat & \\
\hline \multirow{2}{*}{1} & 20 & 8 & 65 & 27 & Lempung Berdebu \\
& 30 & 9 & 55 & 36 & Lempung Liat Berdebu \\
& 10 & 7 & 68 & 29 & Lempung Liat Berdebu \\
\hline \multirow{2}{*}{2} & 20 & 9 & 66 & 25 & Lempung Liat Berdebu \\
& 30 & 19 & 48 & 33 & Lempung Berdebu \\
& 10 & 15 & 47 & 38 & Lempung Liat Berdebu \\
\hline \multirow{2}{*}{3} & 20 & 9 & 56 & 35 & Lempung Liat Berdebu \\
& 30 & 12 & 53 & 35 & Lempung Liat Berdebu \\
\hline
\end{tabular}

Subtrat yang mendominasi di Hutan Mangrove Kelurahan Mamburungan memiliki jenis subtrat lempung liat berdebu, hal ini diduga karena lokasi ini berada di sekitar muara sungai sehingga memiliki lahan terbuka dan genangan air. Substrat yang berada di sekitar muara sungai memiliki tekstur yang lebih halus dan memiliki banyak sumber makanan yang terkandung dalam substrat tersebut serta memiliki bahan makanan dalam sedimen yang lebih banyak, sehingga menyebabkan tingginya nilai kandungan bahan organik.

Sanusi dan Putranto (2009) menyatakan bahwa sedimen yang memiliki tekstur halus biasanya berada pada hilir dan estuari, sedangkan untuk tekstur sedimen kasar biasanya berada pada daerah yang memiliki kondisi arus dinamis seperti daerah yang mengarah ke laut lepas. Pada sedimen yang halus memiliki presentase yang lebih tinggi dari pada sedimen yang kasar, hal ini juga dipengaruhi oleh kondisi lingkungan, dimana lingkungan yang tenang memungkinkan pengendapan lumpur lebih baik sedangkan pada sedimen yang kasar, kandungan sedimennya lebih rendah karena partikel yang lebih halus tidak menegendap (Irmawan, 2010).

Dari hasil penelitian yang telah dilakukan di Kelurahan Mamburungan memiliki kandungan Nitrogen paling tinggi terdapat pada substrat lempung liat berdebu yang mendominasi di lokasi penelitian. Menurut Putri (2016) semakin besar persentase lempung, maka semakin tinggi kandungan bahan organik yang ada dan melimpahnya makrozoobentos.

\section{Kandungan Nitrogen Pada Sedimen Di Hutan Mangrove Mamburungan}

Bahan organik yang terdekomposisi terbawa oleh aliran sungai menuju laut (Bahri, 2010). Aktifitas di dalam ekosistem mangrove seperti guguran daun mangrove yang terdekomposisi menjadi bahan organik dengan bantuan bahan organik juga menghasilkan Fosfor. Nilai kandungan bahan organik dalam satu kawasan terindikasi memiliki nilai yang berbeda dikarenakan lingkungan dan pergerakan air laut yang dinamis (Hawari, 2013). Maka penelitian ini dilakukan di tiga titik stasiun 
berbeda di kawasan Hutan Mangrove Mamburungan pada sedimen dengan kedalaman $10 \mathrm{~cm}, 20 \mathrm{~cm}$ dan $30 \mathrm{~cm}$. Hasil Gambar 3.

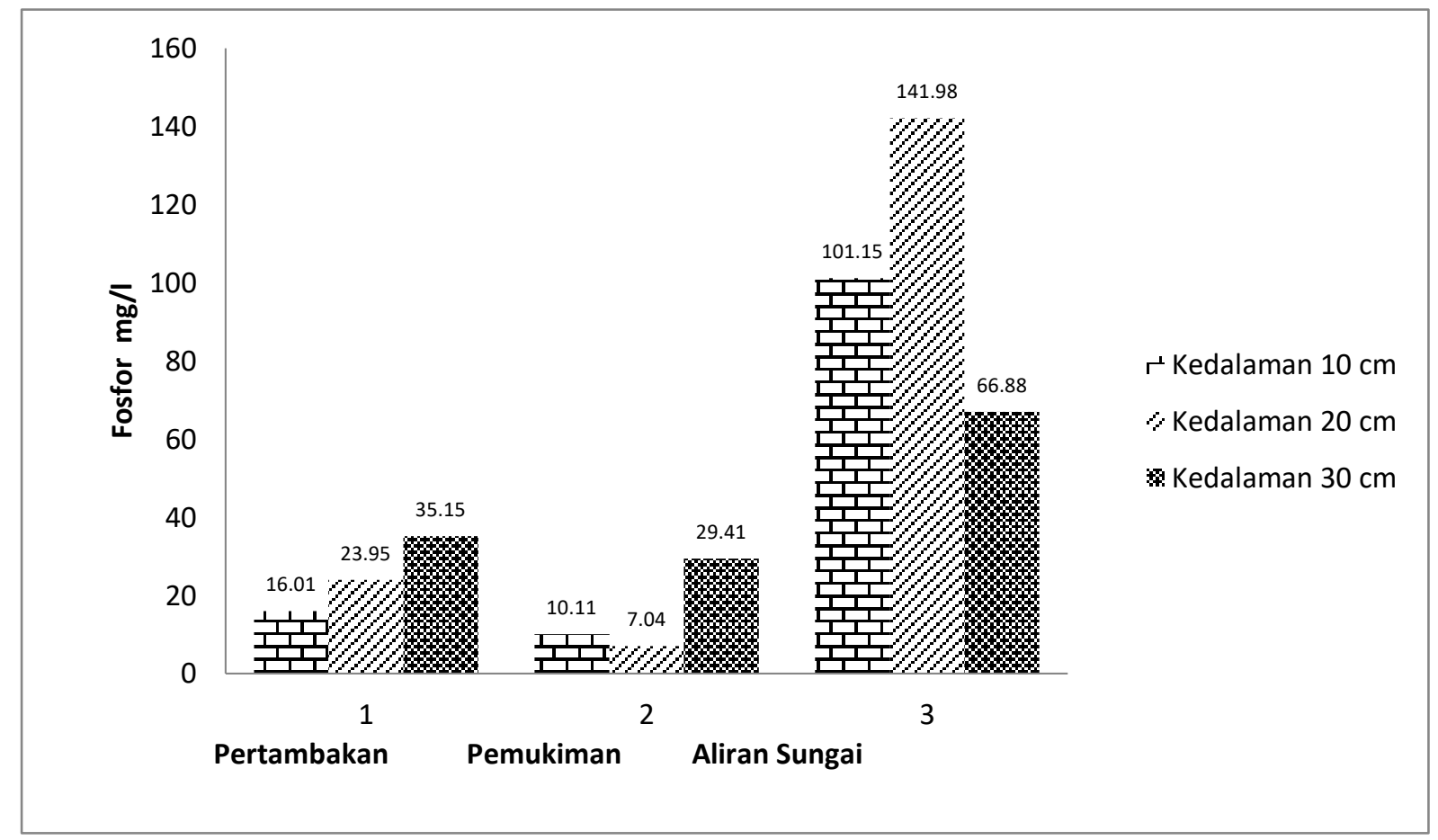

\section{Gambar 3. Kandungan Fosfor Pada Sedimen}

Pada Stasiun 1, kandungan nilai Fosfor yang paling tinggi ditemukan pada kedalaman $30 \mathrm{~cm}$ sebesar 35,15 mg/L dan kandungan terendah ditemukan pada kedalaman $10 \mathrm{~cm}$ sebesar $16,01 \mathrm{mg} / \mathrm{L}$. Tingginya nilai Fosfor pada kedalaman $30 \mathrm{~cm}$ diduga karna tingginya tingkat dekomposisi oleh serasah mangrove dan letak keberadaan lokasidekat area pertambakan, dan permukaan sedimen terkena bilasan oleh aktifitas pasang surut sehingga mengakibatkan bahan organik yang ada di lapisan sedimen dibawahnya stabil dan mengalami peningkatan ditambah lagi subtrat nya yang terdiri lempung berdebu, penyebab material dapat mudah terserap kedalam sedimen. Sedangkan pada kedalaman $10 \mathrm{~cm}$ permukaan sedimen mengandung nilai fosfor yang rendah dikarenakan tidak tersuspensi dengan baik karna aktifitas pasang surut. Mucthar (2012) menyatakan bahwa keberadaan bahan organik dalam sedimen berbeda-beda, kandungan bahan organik didasar perairan mempunyai nilai yang lebih tinggi di bandingkan di permukaan.

Pada Stasiun 2, kandungan nilai Fosfor yang paling tinggi ditemukan pada kedalaman $30 \mathrm{~cm}$ sebesar 29,41 mg/L dan kandungan nilai Fosfor terendah ditemukan pada kedalaman $20 \mathrm{~cm}$ sebesar 7,04 mg/L. Rendahnya niai pada kedalaman $20 \mathrm{~cm}$ diduga disebabkan bahan organik telah terurai dan dimakan oleh organisme dan diserap oleh tanaman mangrove sehingga bahan organik pada lapisan sedimen dibawahnya stabil dan mengalami peningkatan. Subowono (2010) menyatakan bahwa peranan bahan organik dalam tanah berlangsung karena adanya aktivitas organisme tanah, tanpa adanya aktivitas organisme tanah bahan organik akan tetap utuh (tidak terurai). Kandungan Nitrogen di Stasiun 3 paling tinggi ditemukan pada kedalaman $10 \mathrm{~cm}$ yaitu 1,69 $\%$. Proses dekomposisi oleh bakteri yang menghasilkan bahan organik lebih tinggi diduga lokasi ini memiliki tanah yang lembab. 
Pada Stasiun 3, kandungan nilai Fosfor yang paling tinggi ditemukan pada kedalaman $20 \mathrm{~cm}$ sebesar 141,98 $\mathrm{mg} / \mathrm{L}$, sedangkan yang terendah ditemukan pada kedalaman $30 \mathrm{~cm}$ sebesar $66,88 \mathrm{mg} / \mathrm{L}$. Tingginya kandungan Fosfor berasal dari proses mineralisasi dan dekomposisi serasah mangrove, selain itu juga disebabkan oleh faktor lain yaitu lokasi yang berada di daerah aliran sungai. Hal ini didukung oleh penelitian Nugroho et. al. (2013) yang mendapatkan kandungan bahan organik Fosfor pada kedalaman $20 \mathrm{~cm}$ lebih tinggi dibandingkan 10 dan $30 \mathrm{~cm}$. Kedalaman $20 \mathrm{~cm}$ merupakan tempat yang strategis bagi organisme berkembang biak dan melakukan fotosintesis. Selain itu, subtrat pada stasiun 3 terdiri dari lempung liat berdebu yang memiliki sifat padat, sehingga bahan organik tidak mudah terserap hingga kedalaman $30 \mathrm{~cm}$.

Hal lain yang mempengaruhi keberadaan Fosfor yaitu, jenis subtrat, kerapatan tumbuhan mangrove dan kelimpahan organisme yang ada di suatu ekosistem hutan mangrove. Hawari et. al., (2012) menyatakan bahwa bahan organik merupakan sumber makanan bagi biota laut yang pada umumnya terdapat pada substrat dasar sehingga ketergantungannya terhadap bahan organik sangat besar.

Kandungan Fosfor pada sedimen di Hutan Mangrove Mamburungan dikategorikan memiliki kandungan yang tinggi, hal ini sesuai dengan kriteria bahan organik sedimen yaitu : sangat tinggi : $>35 \mathrm{mg} / \mathrm{L}$, tinggi : $17-35 \mathrm{mg} / \mathrm{L}$, sedang : 7-17 mg/L, rendah : 3,5 - $7 \mathrm{mg} / \mathrm{L}$, sangat rendah $<3,5 \mathrm{mg} / \mathrm{L}$ (Wibowo, 2014). Nugroho et. al., (2013) menyatakan bahwa hutan mangrove merupakan penyumbang unsur hara bagi organisme yang hidup di dalamnya dan sekitarnya, dimana besarnya biomassa serasah lantai hutan merupakan petunjuk pentingnya hutan mangrove sebagai sumber bahan organik. Gambaran kandungan Fosfor pada sedimen di beberapa kawasan mangrove lain pada Tabel 3.

\section{Tabel 3. Kandungan Fosfor Pada Sedimen Dibeberapa Kawasan Mangrove}

\begin{tabular}{llll}
\hline No & Lokasi & Kandungan & Sumber \\
\hline \multirow{2}{*}{ 1. } & $\begin{array}{l}\text { Kawasan Mangrove Di Desa Bedono, Kecamatan } \\
\text { Sayung, Kabupaten Demak. }\end{array}$ & $80,42-354,73 \mathrm{mg} / \mathrm{L}$ & Nugroho et al., 2013 \\
\hline 2. & Gunung Anyar, Surabaya & $0,110 \mathrm{mg} / \mathrm{L}$ & Andriawan, 2014 \\
\hline 3. & Bancara, Surabaya & $0,129 \mathrm{mg} / \mathrm{L}$ & Andriawan, 2014 \\
\hline 4. & KKMB Kota Tarakan, Kalimantan Utara. & $26,23-46,71 \mathrm{mg} / \mathrm{L}$ & Sampe, 2017 \\
\hline 5. & Kawasan Mangrove Mamburunga Kota Tarakan. & $7,04-141,98 \mathrm{mg} / \mathrm{L}$ & Penelitian ini, 2018 \\
\hline
\end{tabular}

Kandungan bahan organik Fosfor $(P)$ pada sedimen di kawasan Hutan Mangrove Mamburungan berkisar 7,04 - 141,98 mg/L, hasil ini masih lebih rendah jika dibandingkan dengan hasil penelitian yang berada di kawasan Mangrove Desa Bedona kabupaten Demak dimana kandungan bahan organik Fosfor sebesar 80,42 - 354,73 $\mathrm{mg} / \mathrm{L}$. Hal ini disebabkan oleh kawasan tersebut memliki tingkat kerapatan mangrove yang tinggi, pertumbuhan vegetasi mangrove yang tinggi akan mempengaruhi siklus rantai makanan yang ada pada kawasan tersebut sehingga proses penguraian bahan organik berlangsung dengan baik.selain itu, jenis subtrat kawasan tersebut antara lain lumpur berpasir yang memiliki sifat yang halus, hal ini menyebabkan bahan organik dapat terserap dengan baik.

Kandungan bahan organik Fosfor $(P)$ yang didapatkan pada sedimen di kawasan Hutan Mangrove Gunung Anyar Surabaya, Bancara Surabaya dan Kawasan Konservasi Mangrove Bekantan Kota Tarakan masih lebih rendah jika dibandingkan dengan Kawasan Hutan Mangrove Mamburungan Tarakan. Hal ini diduga disebabkan oleh faktor lokasi seperti daerah pertambakan, daerah pemukiman dan daerah aliran sungai. Penelitian dan keadaan geografis yang berbeda disetiap daerah menyebabkan nilai kandungan berbeda-beda. Manengkey (2010) menyatakan bahwa bahan organik pada sedimen yang terdapat di muara sungai lebih 
tinggi dikarenakan adanya proses mineralisasi yang berada di hulu sungai dan limbah domestik rumah tangga dapat meningkatkan bahan organik.

\section{Kualitas Air}

Parameter kualitas air yang diukur meliputi parameter fisika dan kimia yang menjadi faktor pembatas nilai kandungan bahan organik dan pengaruh pengukuran kualitas air terhadap bahan organik disuatu sedimen perairan. Faktor fisika dan kimia diantaranya salinitas, suhu, derajat keasaman $(\mathrm{pH})$ dan oksigen. Untuk lebih jelasnya dapat dilihat pada Tabel 4.

Tabel 4. Analisis Kualitas Air

\begin{tabular}{lllll}
\hline Parameter & \multirow{2}{*}{ Satuan } & \multicolumn{3}{c}{ Stasiun } \\
\cline { 3 - 5 } & & $\mathbf{1}$ & \multicolumn{1}{c}{$\mathbf{2}$} & $\mathbf{3}$ \\
\hline Suhu & ${ }^{\circ} \mathrm{C}$ & $25-28$ & $26-31,6$ & $27-30,1$ \\
\hline Salinitas & $0 / 00$ & $18-21$ & $20-23$ & $21-25$ \\
\hline $\mathrm{pH}$ & - & $7-7,8$ & $7-7,5$ & $7-7,45$ \\
\hline $\mathrm{DO}$ & $\mathrm{mg} / \mathrm{L}$ & $4,32-5,5$ & $3,40-5,57$ & $4,1-5,10$ \\
\hline
\end{tabular}

\section{Suhu}

Pengukuran suhu yang telah dilakukan di Hutan Mangrove Mamburungan pada masingmasing stasiun berkisar antara $28-31,6{ }^{\circ} \mathrm{C}$. Suhu merupakan faktor pembatas dalam proses pertumbuhan organisme dan distribusi makhluk hidup karena suhu berpengaruh terhadap proses metabolisme suatu organisme, karna dalam proses pembentukan bahan organik membutuhkan organisme pendukung seperti detritus dan bakteri pengurai. Hal ini didukung oleh pendapat Nuraini, (2010) menyatakan bahwa semakin rendah suhu maka kandungan bahan organik akan semakin tinggi dikarenakan proses penguraian bahan organik oleh bakteri semakin cepat.

\section{Salinitas}

Pengukuran salinitas di Hutan Mangrove Mamburungan didapatkan hasil berkisar antara 21 - 25\%o. Terjadinya penurunan atau meningkatnya salinitas pada lokasi ini dipengaruhi oleh adanya aliran air tawar yang berasal dari aliran sungai masuk kedalam kawasan tersebut. Mallin et., al., (2000) menyatakan bahwa semakin tinggi salinitas pada sedimen maka kandungan bahan organik akan semakin rendah hal ini disebabkan karena bakteri pengurai mengalami penghambatan sehingga aktifitas bakteri akan menjadi rendah akibat terjadinya shock osmotic atau toksik.

\section{Derajat Keasaman (pH)}

Nilai $\mathrm{pH}$ merupakan salah satu faktor untuk mengontrol aktifitas dan distribusi organisme yang hidup dalam suatu perairan. Hasil pengukuran $\mathrm{pH}$ di Hutan Mangrove Mamburungan yaitu berkisar antara 7-7,4, berdasarkan hasil pengukuran $\mathrm{pH}$ pada tiap stasiun tidak berbeda jauh dimana $\mathrm{pH}$ dikawasan hutan Mangrove Kelurahan Mamburungan relative stabil/netral. Kushartono (2009) menyatakan bahwa pH pada permukaan sedimen lebih tinggi dari pada lapisan dibawahnya akibat dari serasah yang mengalami dekomposisi pada permukaan lebih banyak sehingga sedimen mempunyai kandungan bahan organik yang tinggi yang menyebabkan sedimen tanah menjadi masam. Semakin tinggi kandungan $\mathrm{pH}$ pada sedimen maka kandungan bahan organik akan semakin rendah hal ini disebabkan oleh karena lambatnya proses penguraian daun mangrove menjadi bahan organik.

\section{Oksigen Terlarut (DO)}

Kandungan oksigen terlarut di dalam perairan memiliki faktor yang sangat penting untuk menunjang kehidupan organisme karena berkaitan erat dengan proses metabolisme makanan yang diperlukan untuk kehidupan organisme itu sendiri. Berdasarkan pengukuran oksigen terlarut di Hutan Mangrove 
Mamburungan berkisar antara 3,40 - 4,32 $\mathrm{mg} / \mathrm{L}$. Terjadinya penurunan oksigen terlarut diduga karena salah satunya faktor cuaca dan panas. Rumalutur (2004) menyatakan bahwa meningkatnya suhu menyebabkan kandungan oksigen berkurang. Semakin rendah nilai DO akan semakin tinggi proses dekomposisi bahan organik di lapisan dasar yang membutuhkan oksigen (Ulquldry, 2010).

\section{KESIMPULAN}

Kandungan bahan organik Fosfor pada Kawasan Hutan Mangrove Mamburungan berdasarkan kedalaman $10 \mathrm{~cm}$ berkisar 10,11 $101,15 \mathrm{mg} / \mathrm{l}$, kedalaman $20 \mathrm{~cm}$ berkisar 7,04 $141,98 \mathrm{mg} / \mathrm{l}$ dan kedalaman $30 \mathrm{~cm}$ berkisar 29,41 - 66,88 mg/l. Berdasarkan hasil yang didapatkan kandungan bahan organik Fosfor pada kawasan Hutan Mangrove Mamburungan kota Tarakan tergolong sangat tinggi.

\section{DAFTAR PUSTAKA}

Bahri, A. F. 2010 Analisis Nitrat dan Fosfat pada Sedimen Mangrove. [skripsi]. UNDIP. Semarang.

BPS [Badan Pusat Statistik]. (2015). Tarakan Dalam Angka. Tarakan.

Feller, I., Lovelock, C.E., Berger, U., Mckee,K.L., Joye, S.B., \& Ball, M.C. (2010). Biocomplexity in Mangrove Ecosystems. Anual Review of Marine Science. [Tesis]. Corvallis.

Hawari, A.B. Amin, Efriyeldi. (2013). Hubungan Antara Bahan Organik Sedimen dengan Kelimpahan Makrozoobenthos di Perairan Pantai Pandan. [Tesis]. Fisheries and Marine Science Faculty Universitas of Riau. Sumatra Utara.

Kushartono. A. W. (2009). Beberapa Aspek BioFisik Kimia Tanah di Daerah Mangrove Desa Pasar Banggi Kabupaten Rembang. Journal IImu Kelautan. 14(2): $76-83$.

Mahasani, I.G.A.I., Widagti, N., \& Karang, I.W.G.A. (2015). Estimasi Presentase Karbon Organik Dihutan Mangrove Bekas Tambak Perancak Jembrana. [Tesis]. Bali.
Mallin, M. A., Williams, K. E., Esham, E.C., Lowe, R. P. (2000). Effect of Human Development on Bacteriological Water Qualitative in Coastal Watershed. [Tesis]. Ecol Appl. 10: 1047 - 1056.

Manengki. (2010). Kandungan Bahan Organik Pada Sedimen di Perairan Teluk Buyat dan Sekitarnya. Jurnal Perikanan dan Kelautan Tropis. [Tesis]. 5(3): 114 119.

Mardi. (2014). Keterkaitan Struktur Vegetasi Mangrove Dengan Keasaman dan Bahan Organik Total Sedimen pada Kawasan Suaka Margasatwa Mampie di Kecamatan Wonomulyo Kabupaten Polewali Mandar. [skripsi]. UNHAS. Makassar.

Muchtar, M. (2012). Distribusi Zat Hara, Nitrat dan Silikat di Perairan Kepulauan Natuna. Jurnal IImu Kelautan dan Teknologi Kelautan Tropis. 4(2): 304317.

Nugroho. R. A, S. Widada, R. Pribadi. (2013). Studi Kandungan Bahan Organik dan Mineral (N,P,K,Fe dan Mg) Sedimen di Kawasan Mangrove Desa Bedono, Kecamatan Saying. Journal Of Marine Research. [Tesis]. Kabupaten Demak. 2 (1): 62- 67.

Nuraini. S. (2010). Kadar Air dan Bahan Organik Tanah. Penerbit Kanisius. Yogyakarta.

Rosmarkam, A. (2002). Ilmu Kesuburan Tanah. penerbit kansius. Yogyakarta.

Rumalutur, L. M. 2004. Komposisi Jenis Gastropoda pada Komunitas Hutan Mangrove di Pulau Tameni dan Pulau Raja Desa Gita, Kabupaten Halmahera Tengah Maluku Utara [Skrips]. Program Sarjana Fakultas Perikanan dan Ilmu Kelautan Institut Pertanian Bogor. Bogor.

Sanusi, H.S., DAN Putranto. (2009). Kimia dan Interaksinya dengan Lingkungan. Departemen Ilmu dan Teknologi Kelautan, Fakultas Perikanan dan Ilmu Kelautan, Institus Pertanian Bogor. Bogor. 
JURNAL BORNEO SAINTEK

Volume 2, Nomor 1, April 2019

e-ISSN 2599-3313

p-ISSN 2615-434X

Sugiyono. (2016). Metode Penelitian Pendidikan, penerbit Alfabeta. Bandung.

Sutanto, R. (2005). Dasar-Dasar Ilmu Tanah, Konsep dan Kenyataan. Kanisius. Yogyak arta. Hal. 36.

Ulquldry. (2010). Karakteristik dan Sebaran Nitrat, Fosfat dan Oksigen Terlarut di Perairan Karimunjawa Jawa Tengah. Jurnal Penelitian Sains. Semarang.

Wibowo, E. (2004). Beberapa Aspek Bio-FisikKimia Tanah Daerah Hutan Mangrove
Available online at www.jurnal.borneo.ac.id

Halaman 46-55

$\begin{array}{lll}\text { Desa Pasar } & \text { Banggi } & \text { Kabupaten } \\ \text { Semarang. } & \text { [Tesis]. } & \text { Universitas }\end{array}$

Diponegoro. Semarang.

Wiharyanto, D., dan Laga. A. (2010). Kajian

Pengelolaan Hutan Mangrove di

Kawasan Konservasi Desa

Mamburungan Kota Tarakan Kota

Tarakan Kalimantan Timur. Jurnal

Media Sains. Vol.2 (1):

10-17. 